UDC 621.398

DOI: https://doi.org/10.26642/tn-2019-1(83)-126-130

S.O. Fomenko, Master Student

T.M. Loktikova, Senior lecturer N.O. Kushnir, Junior researcher A.V. Morozov, Ph.D., Ass.Prof. Zhytomyr polytechnic state university

\title{
The development of the multifunctional device for the information and control telemechanical complex
}

The article presents the development of the multifunctional device for the information and control telemechanical complex with the use of the signal microcontroller. The multifunctional device provides three telemechanical functions: telecontrol, telemeasuring of current values of parameters, telesignaling. Thus, the proposed device combines the three most important functional modules of the information and control telemechanical complex - the module for receiving telecontrol commands, the module for inputting telemeasurement of the current values of parameters, the module for the input of discrete signals. This is important in cases where the number of sensors, executive mechanisms that are located on the device of the controlled point of the telemechanical complex is small. Instead of using several full functional modules of various types, it is possible to use one multifunctional module. The structural scheme, algorithm of the work of the developed device are described. The signal microcontroller STM32F407VET6 is the basis of the scheme of the device. In addition to the multifunctionality, the developed device is characterized by high reliability, low power, wide range of operating temperatures.

Keywords: telemechanics; telecontrol; telemeasurement; telesignaling; information and control telemechanical complex; signal microcontroller.

\section{Problem statement}

One of the principles of constructing devices of modern information and control telemechanical complexes (ICTC) is the highway-modular principle. In accordance with this principle a device is composed of following: internal highway; controller internal line; various types of modules that provide the execution of appropriate telemechanical functions.

The structure of the device of the point under control or RTU ICTC, built on the highway-modular principle, is shown in Fig. 1.

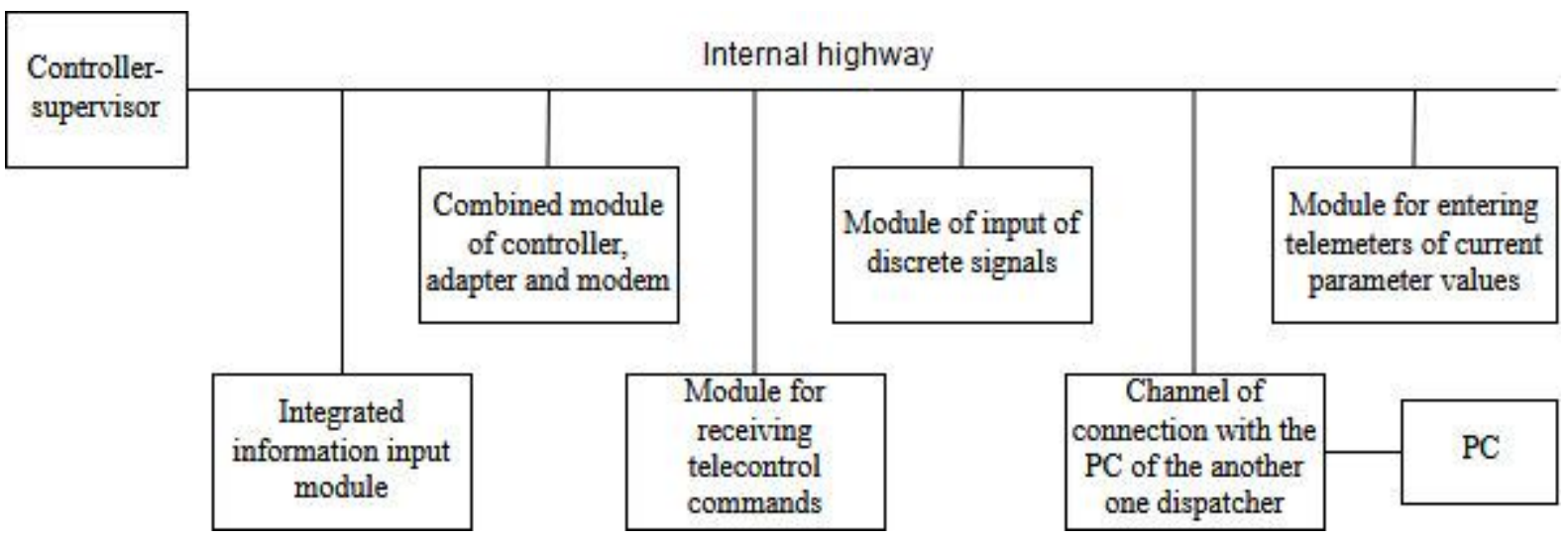

Figure 1. The structure of the point under control

Internal highway lines are used for transmission-receiving control, address and information signals.

The internal line controller is the hub of supervisor control that regulates data exchange between the RTU and the processing center of control unit.

Depending on the particular application, the number of sensors of various signals, executive mechanisms that are located on the device of the controlled point (RTU) may be small. Therefore, instead of using several full functional modules of different types, it would be efficient to use a multifunction module that would provide multiple telemechanical functions and would be designed to work with small number of objects and sensors. 
The purpose of the paper

It is proposed to develop a multifunctional device for information control telemechanical complex. The multifunctionality of the presented device is in combination of three most important functional modules of ICTC. They are: the module receiving commands of telecontrol, the module for inputting telemeasurement of the current values of parameters, the module for the input of discrete signals, which provides the implementation of the corresponding basic telemechanical functions - telecontrol (TC), telemeasurement (TM), telesignaling (TS).

The presentation of the main material

The multifunction device is designed to receive telecontrol commands, to generate control signals for executive mechanisms (relays), to perform sporadic telemetry of current values of parameters when the signal from the sensor is changed by amount exceeding a certain threshold, to receive commands to call data from the control point device, which are fetch instructions of discrete signals.

Multifunctional device provides control of two objects; input, transformation and processing of analog signals from four sensors of telemetry $0 \ldots 5 \mathrm{~mA}$, minus $5 \ldots 0 \ldots+5 \mathrm{~mA}, 0 \ldots 20 \mathrm{~mA}, 4 \ldots 20 \mathrm{~mA}$; input of discrete signals from eight sensors of telemetry signals.

In order to ensure the execution of these functions the algorithm of operation and the block diagram of the multifunctional device were developed.

The structural chart of the multifunctional device of the information control telemechanical complex is shown in Fig. 2.

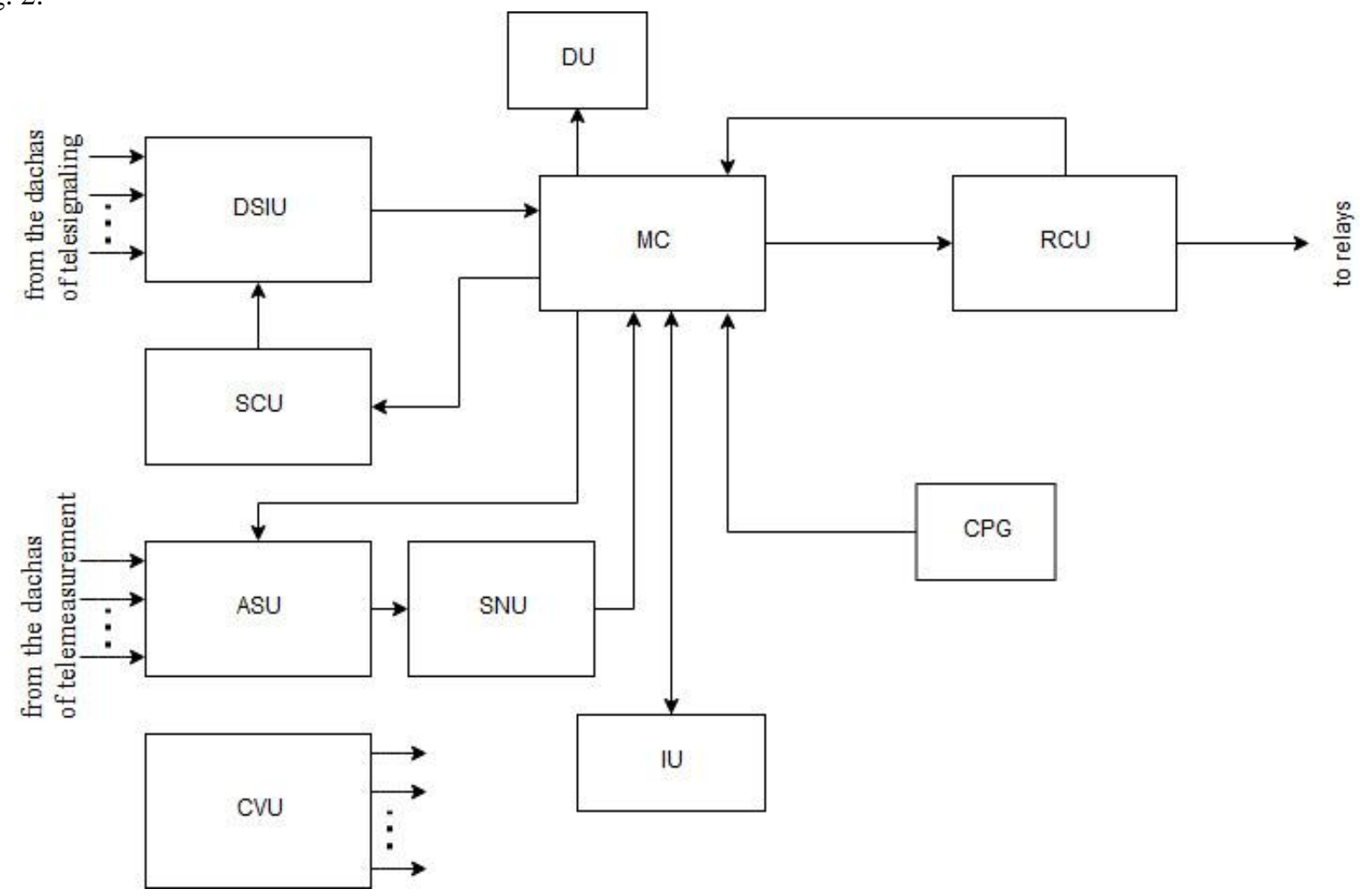

Figure 2. The flow chart of information and control telemechanical complex multifunctional device

The following main units can be highlighted as a part of the device:

$\mathrm{MC}$ - microcontroller;

ASU - analog switching unit;

SNU - signal normalization unit;

DSIU - discrete signal input unit;

RCU - relay control unit;

DU - display unit;

CVU - constant voltage unit;

IU - interface unit;

SCU - self-checking unit;

SU - supply unit;

$\mathrm{CPG}$ - clock pulse generator.

Control unit is the most important and responsible one, therefore, STM32F407VET6 microcontroller was selected. 


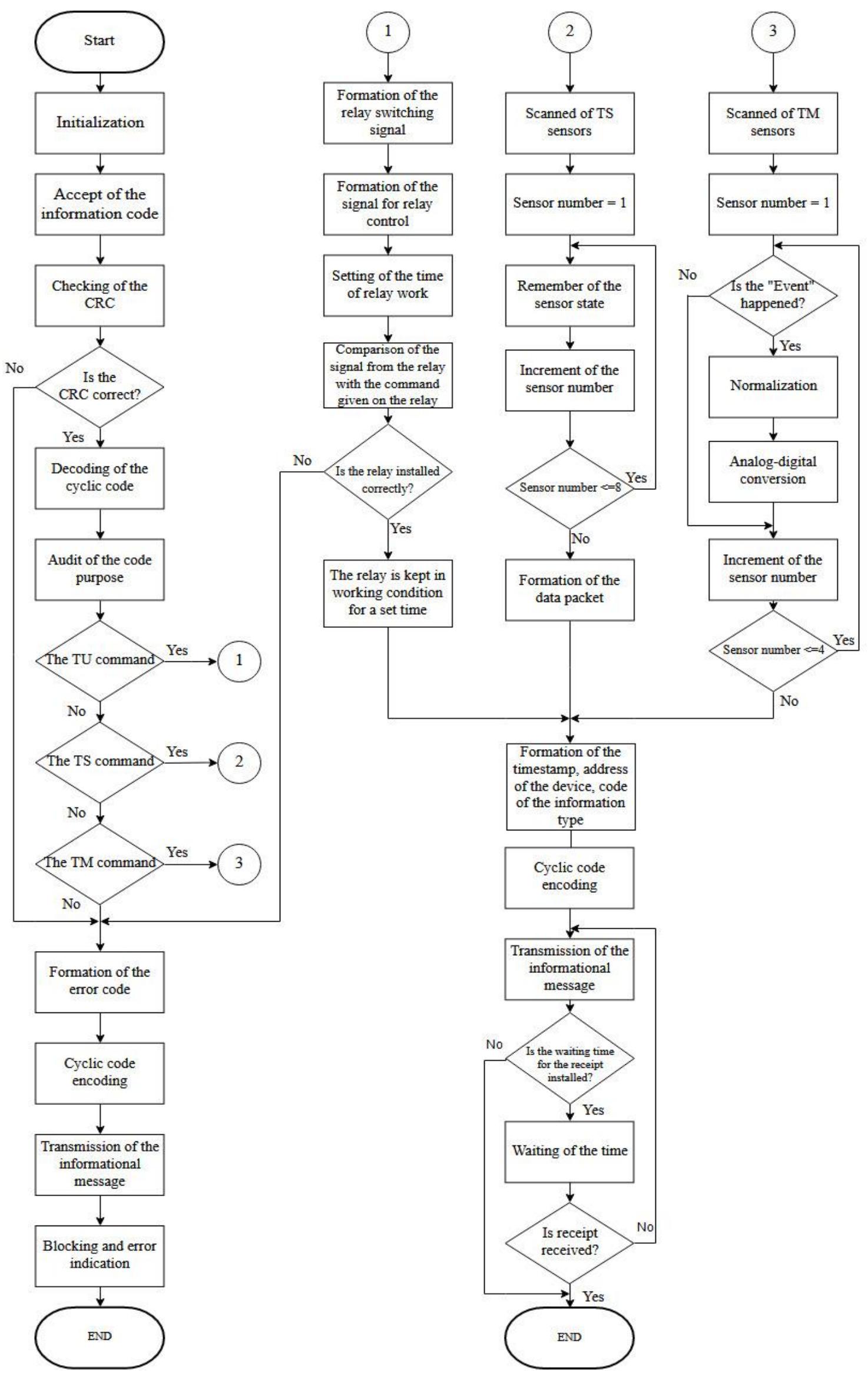

Figure 3. The algorithm of information and control telemechanical complex multifunctional device 
This MC is a high-performance, economical microcontroller based on the ARMCortex-M4 architecture. It should also be noted that the STM32F407VET6 microcontroller belongs to a new promising group of microcontrollers, namely, signal microcontrollers that support DSP (Digital Signal Processing) Instructions. The main circuit parameters of the MK STM32F407VET6 are:

- clock frequency - $168 \mathrm{MHz}$

- bit - 32 bits;

- FLASH capacity - 1 Mbyte;

- capacity of RAM - 192 kbytes;

- number of lines of input-output - 82;

- communication interfaces - I2C, USART, SPI, CAN, USB OTG, Ethernet;

- range of operating temperatures - minus $40 \ldots+1050 \mathrm{C}$;

- supply voltage $-1.8 \ldots 3.6 \mathrm{~V}$.

Combining construction features of $\mathrm{MC}$, it perfectly suites the implementation of modern ITTC, since it satisfies all the requirements for the element base of the telemechanics system, namely: high reliability, low power consumption, wide operating temperature range.

The flow chart of the algorithm of the multifunctional device for information and control telemechanical complex is presented in Fig.3.

Let us consider the principles of the multifunction device.

After initialization has been completed, the device goes into standby for a call command. The call command is received from the internal highway of the device via SPI interface. The call command includes the device address, the corresponding command and the frame code check sequence (CRC).

Next, a CRC message is checked: if the CRC is not correct, an error code is generated and the corresponding information message is transmitted. Also, the device is locked and the error signal is displayed.

If the CRC is correct, the command is checked to identify if it belongs to one of the types: the TU command, the TC command, and the TM command. Provided that the message does not belong to any of the listed types, an error code is generated and the corresponding information message is transmitted.

After the reliability of the received telecontrol command has been checked, signals are generated to switch on relay as well as signals to control object number relay.

Since relays must be kept in working condition for some time, timeout is set for this time interval.

Next, the signals from the indicated relays are compared to the commands that were presented on the relay. These procedures occur during the formation of the corresponding signals.

If relay object number is set correctly, signals are generated to control relay - the type of telecontrol command ("switch on" or "switch off").

Relay is maintained in its operating mode for a set time interval, which ranges from 0.1 to $40 \mathrm{sec}$.

After verifying the accuracy of the received remote signaling command, telesignal sensors are scanned.

Sensors are scanned step-by-step, from first to eighth, and their current state is remembered. Upon completion of testing all sensors, data package is formed for the further transmission of corresponding notification.

If the received information code corresponds to telemetry call command, telemetry sensors are sequentially scanned. The signal from each sensor is subjected to normalization and analog-to-digital conversion.

When sending a corresponding notification, time marker is formed as well as the device address of the controlled point, information type code and frame code check sequence are generated.

It is possible to set waiting time for verification of the transmitted information from the control center device in the range from 1 to $255 \mathrm{sec}$. If it does not happen within the waiting time, retransmission of the information message is performed.

Conclusions. The circuit diagram of the multifunctional device and the software for the microcontroller were also developed. At the same time the modern element base was applied. The basis of the developed device is the STM32F407VET6 microcontroller, which controls it. The program is written in C language. The experimental tests of the developed device were carried out. Thanks to modernity and high level of technical solutions, which are the basis for building a multifunctional device, its high reliability, low power consumption, a wide range of operating temperatures were achieved, which is very important for devices of information and control telemechanical complexes.

Список використаної літератури:

1. Кушнір Н.О. Застосування сигнальних мікроконтролерів при розробці пристроїв інформаційно-управляючих телемеханічних комплексів : тези доповідей X Міжнародної науково-технічної конференції «Інформаційнокомп'ютерні технології 2019» (м. Житомир, 18-20 квітня 2019 року) / Н.О. Кушнір, Т.М. Локтікова, С.О. Фоменко. - Житомир, 2019.

2. Локтікова T.M. Багатофункціональний пристрій для інформаційно-управляючого телемеханічного комплексу : тези Всеукраїнської науково-практичної конференції здобувачів вищої освіти і молодих учених, присвяченої Дню науки (м. Житомир, 15-17 травня 2019 року) / Т.М. Локтікова, С.О. Фоменко, Н.О. Кушнір. - Житомир, 2019.

3. Система автоматичного конфігурування телемеханічних засобів SCADA - системи / О.Р. Кульчицький, T.М. Локтікова, А.В. Морозов, О.С. Іщенко // Вісник інженерної академії України. - 2018. - № 3. - С. $79-85$. 
4. Локтікова T.M. Дослідження сучасного стану та тенденцій розвитку інформаційно-управляючих телемеханічних комплексів : тези доповідей IX Міжнародної науково-технічної конференції «Інформаційнокомп'ютерні технології 2018» (м. Житомир, 20-21 квітня 2018 року) / Т.М. Локтікова, О.Р. Кульчицький, В.А. Большой. - Житомир, 2018. - С. 176-177.

5. Методи та засоби обробки і передачі інформації в системах і мережах передачі даних : навч. посібник / T.M. Локтікова, А.В. Морозов, В.А. Большой, Н.О. Кушнір. - Житомир : Житомирський державний технологічний університет, 2015. - $162 \mathrm{c}$.

6. Бугаев В.И. Лабораторный практикум по изучению микроконтроллеров архитектуры ARM Cortex-M4 на базе отладочного модуля STM32F4 Discovery : учеб. пособие / В.И. Бугаев, М.П. Мусиенко, Я.М. Крайныл. - Москва ; Николаев : МФТИ-ЧГУ, 2013. - $71 \mathrm{c.}$

7. Trevor Martin The Insider's Guide To The STM32 ARM Based Microcontroller / Martin Trevor. - Hitex (UK) Ltd., 2008. $-96 \mathrm{p}$.

8. Сороко В.И. Автоматика, телемеханика, связь и вычислительная техника на железных дорогах России : энциклопедия. Т. 1. / В.И. Сороко, В.М. Каинов, Г.Д. Казиев. - М. : НПФ «ПЛАНЕТА», 2006. - 736 с.

9. Портнов Е.М. Системотехника современных информационно-управляющих комплексов / Е.M. Портнов, А.C. Ищенко // Вісник інженерної академії України. - 2006. - № 1. - С. 39-46.

10. Портнов E.M. Анализ состояния производства, принципов построения и тенденций развития информационноуправляющих комплексов для АСУ распределенных энергообъектов и производств / Е.М. Портнов. - М. : МИЭТ, 2002. - $78 \mathrm{c}$.

\section{References:}

1. Kushnir, N.O., Loktikova, T.M. and Fomenko, S.O. (2019), «Zastosuvannja sygnal'nyh mikrokontroleriv pry rozrobci prystroi'v informacijno-upravljajuchyh telemehanichnyh kompleksiv», Tezy dopovidej X Mizhnarodnoi' naukovotehnichnoi' konferencii' «Informacijno-komp'juterni tehnologii' 2019», Zhytomyr, Ukrai'na, 18-20 kvitnja 2019 roku.

2. Loktikova, T.M., Fomenko, S.O. and Kushnir, N.O. (2019), «Bagatofunkcional'nyj prystrij dlja informacijnoupravljajuchogo telemehanichnogo kompleksu», Tezy Vseukrai'ns'koi' naukovo-praktychnoi' konferencii' zdobuvachiv vyshhoi' osvity i molodyh uchenyh, prysvjachenoi' Dnju nauky, Zhytomyr, Ukrai'na, 15-17 travnja 2019 roku.

3. Kul'chyc'kyj, O.R., Loktikova, T.M., Morozov, A.V. and Ishhenko, O.S. (2018), «Systema avtomatychnogo konfiguruvannja telemehanichnyh zasobiv SCADA - systemy», Visnyk inzhenernoi' akademii' Ukrai'ny, No. 3, pp. 79-85.

4. Loktikova, T.M., Kul'chyc'kyj, O.R. and Bol'shoj, V.A. (2018), «Doslidzhennja suchasnogo stanu ta tendencij rozvytku informacijno-upravljajuchyh telemehanichnyh kompleksiv», Tezy dopovidej IX Mizhnarodnoi' naukovo-tehnichnoi' konferencii' "Informacijno-komp'juterni tehnologii' 2018», Zhytomyr, Ukrai'na, 20-21 kvitnja 2018 roku, pp. 176-177.

5. Loktikova, T.M., Morozov, A.V., Bol'shoj, V.A. and Kushnir, N.O (2015), Metody ta zasoby obrobky i peredachi informacii' $v$ systemah i merezhah peredachi danyh, navchal'nyj posibnyk, Zhytomyrs'kyj derzhavnyj tehnologichnyj universytet, Zhytomyr, $162 \mathrm{p}$.

6. Bugaev, V.I., Musienko, M.P. and Krainyk, Ya.M. (2013), Laboratornyi praktikum po izucheniyu mikrokontrollerov arkhitektury ARM Cortex-M4 na baze otladochnogo modulya STM32F4 Discovery, uchebnoe posobie, MFTI-ChGU, Moskva, Nikolaev, $71 \mathrm{p}$.

7. Trevor Martin (2008), The Insider's Guide To The STM32 ARM Based Microcontroller, Hitex (UK) Ltd., $96 \mathrm{p}$.

8. Soroko, V.I., Kainov, V.M. and Kaziev, G.D. (2006), Avtomatika, telemekhanika, svyaz' i vychislitel'naya tekhnika na zheleznykh dorogakh Rossii, entsiklopediya, NPF «PLANETA», M., Vol. 1, 736 p.

9. Portnov, E.M. and Ishchenko, A.S. (2006), «Sistemotekhnika sovremennykh informatsionno-upravlyayushchikh kompleksov»», Visnyk inzhenernoi' akademii' Ukrai'ny, No., 1, pp. 39-46.

10.Portnov, E.M. (2002), Analiz sostojanija proizvodstva, principov postroenija i tendencij razvitija informacionnoupravljajushhih kompleksov dlja ASU raspredelennyh jenergoob'ektov i proizvodstv, MIJeT, M., 78 p.

Fomenko Serhii Oleksandrovych - master of department of automation and computer-integrated technologies named after prof. B. B. Samotokin of Zhytomyr State Technological University.

Research interests:

- information systems and technologies.

Kushnir Nadia Oleksandrivna - junior researcher of Zhytomyr State Technological University.

Research interests:

- combinatorial optimization;

- information technologies.

Loktikova Tamara Mykolaivna - senior lecturer of the department of software engineering of Zhytomyr State Technological University.

Research interests:

- digital signal processing;

- information systems and technologies.

Morozov Andrii Vasyliovych - Vice rector on scientific and pedagogical work of Zhytomyr State Technological University.

Research interests:

- combinatorial optimization;

- information technologies. 